\title{
Attitudes of Students Enrolled in the Pedagogical Formation Programs towards the Teaching Profession
}

\author{
Yalçın Özdemir ${ }^{1} \&$ Sabri Güngör ${ }^{2}$ \\ ${ }^{1}$ Faculty of Education, Ömer Halisdemir University, Niğde, Turkey \\ ${ }^{2}$ Faculty of Education, Kafkas University, Kars, Turkey \\ Correspondence: Yalçın Özdemir, Faculty of Education, Ömer Halisdemir University, Merkez Yerleşke, Bor Yolu \\ Üzeri, 51240, Merkez, Niğde, Turkey
}

Received: April 11, 2017

Accepted: May 5, 2017

Online Published: May 16, 2017

doi:10.5430/ijhe.v6n3p57

URL: https://doi.org/10.5430/ijhe.v6n3p57

\begin{abstract}
This study was conducted to examine the attitudes of students enrolled in the pedagogical formation programs in order to become teachers towards the teaching profession. The students either graduated from faculties other than the education faculty or they were still enrolled in undergraduate programs of faculties other than the education faculty. The study group is made up of randomly selected 491 students enrolled in the pedagogical formation programs of Kafkas University and Ömer Halisdemir University during the 2016-2017 academic year between 6 and 15 January, 2017. To collect the study data, "Attitude Scale towards Teaching Profession" was used. Arithmetic mean, independent t-test, one-way analysis of variance (ANOVA) and LSD post hoc tests were conducted in the analysis and interpretation of data. In the study, it was determined that as the ages of students enrolled in the pedagogical formation programs increase, they showed more positive attitudes towards the teaching profession. Females had more positive attitudes than males, graduates more than students, Ömer Halisdemir University students more than Kafkas University students, and students who lived mostly in urban areas more than students who live in rural areas. Furthermore, according to the study results, teaching profession attitudes of students enrolled in pedagogical formation programs differ according to their faculty, mother and father's education and monthly family income.
\end{abstract}

Keywords: Teaching profession attitude, Pedagogical formation education, University students, Teacher candidates

\section{Introduction}

The social, political and economic functions attributed to education today indicate that education is positioned as the most important key to social development. Educational systems will effectively continue their existence as long as they answer the changes in the conditions of social reality they are in. Therefore, as Donaldson (2013) pointed out, especially in societies where continuous and rapid changes take place, continuous development is not an option but a necessity. For this reason, the need for continuous development in education has led many countries in the world to reform their educational systems in line with social expectations. Teachers are the most important component of the effort to improve educational systems in such a way that they can answer the social expectations which continuously and rapidly change and transform. Indeed, the teacher factor is considered as the most important factor affecting the education system (Karagözoğlu, 1987; Oktay, 1991; Donaldson, 2013; OECD, 2005).

The teaching profession can be considered as the art of raising the next generations as good people and good citizens who are helpful and constructive to their families, environment, state and country (Tekışık, 1987) and the human development practice promising intellectual development, humanitarian awareness, economic opportunities, citizenship awareness and other virtues to the individuals who will practice this profession (Cohen, 1988). The improvement of the teaching profession's conditions and professional qualities of the teachers should be positioned at the center of the social development effort. Teachers' professional knowledge levels, their content knowledge levels and their experience levels are some of the factors among teaching qualifications. However, besides all this knowledge, skill and experience, having positive feelings, thoughts and thus attitudes towards the teaching profession can be considered a factor directly affecting at what level individuals who will become teachers will realize the knowledge and skills they have. No matter how high the knowledge, skills and experience the teacher candidates have, if they are not interested in the teaching profession, if they are doing the job out of necessity or if they do not respect the profession, they cannot be expected to use their knowledge and skills in their true sense. In 
this context, examining teacher candidates' feelings, thoughts and attitudes towards the teaching profession can be considered as the most important factor in improving teacher training processes and thus improving educational systems.

\subsection{Attitude and Attitudes towards the Teaching Profession}

In the Big Dictionary of Turkish Language Institution, the concept of attitude is defined as behavior forms individuals engage in the face of people, events and inanimate objects (Turkish Language Institution [TDK], 2017). While attitudes appear to be behavior forms according to this definition, attitudes are not limited to only observable behaviors. Indeed, it is a concept including some phenomena such as feeling, thought and belief. Attitudes are our tendencies in assessing phenomena (Katz, 1960; Rokeach, 1967). Therefore, attitudes have the power affecting the direction, quality and quantity of our behaviors regarding a phenomenon. In this context, attitudes have an epistemological power like Prislin and Crano (2010) stated:

Attitudes represent an evaluative integration of cognitions and affect experiences in relation to an object. Attitudes are the evaluative judgments that integrate and summarize these cognitive/affective reactions. These evaluative abstractions vary in strength, which in turn has implications for persistence, resistance, and attitude-behavior consistency (Prislin \& Crano, 2006, 347 cited in Prislin \& Crano, 2010).

In that case, attitudes can be described as crystallized fundamental social forces helping to shape not only our behaviors at a certain time but also to shape our future behaviors (Anderson, 1928). Thus, attitudes can be considered as a phenomenon involving our views and opinions regarding any phenomenon as well as our beliefs (Katz, 1960; Pajares, 1992; Valcke et al., 2010).

When we discuss the concept of attitude in this context, individuals' attitudes towards a certain profession does not only involve individuals' feelings, thoughts or beliefs towards a certain profession. Individuals' attitudes also have the power to shape the practices within that profession, i.e. how the profession is performed. Therefore, while individuals' attitudes towards a certain profession reflect individuals' awareness of the profession's benefits and value within the society, they also reflect individuals' willingness to be part of the profession and their love, commitment and devotion to the profession (Khalid \& Amir, 2014). For this reason, there is a position relationship between individuals having positive attitudes towards a certain profession and the quality of that profession's execution.

Unlike other individuals, teacher candidates are individuals who generally experience a significant part of the professional processes they will perform during their student lives or specifically during student lives in their teacher training programs. Therefore, as opposed to graduates of other academic disciplines, teacher candidates participate teacher training programs with already having practical experiences regarding their profession and attitudes shaping these experiences (Pajares, 1992; Valcke et al., 2010). According to Pajares (1992), teacher candidates' attitudes towards the teaching profession is quite resistant to change. Similarly, Kagan (1992) stated that teacher candidates' attitudes they already had before entering the teacher training programs can be changed very little with the knowledge they gained during the teacher training programs. On the contrary, Kagan (1992) expressed that attitudes affect how much knowledge will be gained in the programs and how this knowledge will be interpreted. The way knowledge and skills about teaching are interpreted and the way experiences lived during teaching are interpreted affect the identity of the teachers (Flores, 2001). Similarly, it can be said that teacher candidates' attitudes towards the teaching profession will affect their professional identities. Teacher candidates' attitudes about the meaning and value of teaching and attitudes about how much they will be compatible to the profession they have while they are in teacher training programs and while they are performing the teaching profession will shape the responses they will give to the changing conditions of teaching. In this sense, attitudes towards the teaching profession may affect the teacher quality and perhaps teacher quantity by influencing the definition of the right ways to become a teacher (Lasky, 2005) and by influencing the internalization of the innovations in the teaching profession (Beijaard et al., 2000). For example, Dikmenli and Çiftçi (2016) point out that teachers who have positive attitudes towards classroom management as a component of the teaching profession will spend more effort on their students. Therefore, attitudes towards the teaching profession as a whole will also have an impact on the qualifications of education and teaching processes. In this context, understanding teacher candidates' attitudes towards the teaching profession and taking into account these attitudes in teacher training programs are necessary (Watt \& Richardson, 2008). Indeed, although some studies (Hollingsworth, 1989) acknowledge that teacher candidates come to teacher training programs with attitudes towards teaching, they also determined that the conditions of these programs can change teacher candidates' attitudes. 
In the literature, there are many studies on examining teacher candidates' attitudes towards the teaching profession (Eraslan \& Çakıc1, 2001; Özkan, 2012; Polat, 2013). These studies largely focus on the relationships between teacher candidates' demographic characteristics and their attitudes. Notably, however, there are scarcely any studies about whether the universities where the teaching training programs are affected attitudes or not. In this study, it is aimed to determine and analyze the teacher candidates' attitudes towards the teaching profession. The study will also try to answer the question of whether teacher candidates' demographic characteristics in addition to their attitudes significantly change or not according to the universities where the teaching training program is given. Thus, it is hoped that the study will fulfill the need in the literature. In the study, teaching profession attitudes of teacher candidates' enrolled in the pedagogical formation certificate programs, one of the teacher training processes in Turkey, were examined. These programs train students who are enrolled or graduated in faculties other than the education faculties. In a way, pedagogical formation certificate programs are the programs offering teacher training to those who are studying at faculties other than education faculties but who decided to become teachers later on.

\section{Methods}

\subsection{Research Model}

Aiming to examine attitudes of students enrolled in pedagogical formation certificate programs towards the teaching profession, the study employs the survey model. Survey models are approaches that aim to describe a past or present situation as it is and that define the event, individual or object in the study as it exists within its own circumstances. In this research model, efforts to change or affect the events in any way are not made (Karasar, 2012).

\subsection{Study Group}

The study group is made up of randomly selected 491 students enrolled in the pedagogical formation certificate programs of Kafkas University and Ömer Halisdemir University in Turkey during the 2016-2017 academic year. These 491 students were students or graduates of faculties of arts and sciences, faculty of economics and administrative sciences (FEAS) and schools of physical education and sports (SPEA). These faculties were the common ones among the students who went to these universities.

\subsection{Data Collection Tools}

The study data was collected using "Personal Information Form" and "Attitude Scale towards Teaching Profession" developed by Çetin (2006).

\subsubsection{Attitude Scale towards Teaching Profession}

Developed by Çetin (2006), Attitude Scale towards Teaching Profession scale made up of a total of 35 items (15 positive and 20 negative items). Five ordered response levels, "strongly disagree", "disagree", "no opinion", "agree", "strongly agree", were used. The positive statements were scored 5, 4, 3, 2, and 1 from "strongly disagree" to "strongly agree" response, and the negative statements were scored reversely. The scale's reliability and validity were done on the data obtained from 341 people selected through random sampling method among the senior students of the education faculty. The scale consists of three sub-dimensions, "affection", "value" and "harmony". The total variance explained by these three sub-dimensions is $51.2 \%$. As a result of the factor analysis conducted in order to determine the validity of the study, it was found that factor loadings of the scale items varied between 0.48 and 0.80 and that Kaiser-Meyer Olkin (KMO) value was 0.95. It was also found that Coefficient of internal consistence (Cronbach's alpha) calculated for the reliability was $\alpha=0.95$. The Cronbach's alpha value for all three dimensions was calculated as $\alpha=.95, \alpha=.81, \alpha=.76$, respectively. Findings regarding the validity and reliability show that the scale has a valid and reliable structure (Çetin, 2006).

\subsubsection{Personal Information Form}

Developed by the researchers, Personal Information form was used to collect students' personal information. This form includes age, sex, education status (graduate, student), university, longest lived settlement, faculty, mother's education level, father's education level and monthly family income.

\subsection{Procedure}

The data collection of the study was carried out during the fall semester of 2016-2017 academic year. The scales were distributed to the participants who volunteered for the study. The study purpose was explained to the participants, and then a brief explanation was given about the data collection tool. They were then given 30 minutes and asked to fill the measurement tools. The researchers were in the classrooms while the participants filled the data collections tools and answered the questions asked by the participants. The data collection process was completed within one week. 


\subsection{Data Analysis}

One-way analysis of variance was used to determine whether pedagogical formation students' attitudes towards the teaching profession differ according to students' ages (20-21, 22-23, 24-25, 26 and over). Independent t-test was used to determine whether students' attitudes towards the teaching profession differ according to sex (female-male), education level (graduate-student), university (Kafkas-Ömer Halisdemir) and longest lived settlement (rural- urban). The significance level was considered to be 0.05 . SPSS 20.0 software was used for statistical analyses.

\section{Results}

\subsection{Socio-demographic Characteristics of Participants}

Table 1 shows the socio-demographic characteristics of participants participating in the study.

Table 1. Socio-demographic characteristics of participants

\begin{tabular}{|c|c|c|c|c|c|c|c|}
\hline \multirow{2}{*}{$\begin{array}{l}\text { Socio-demographic } \\
\text { Characteristics }\end{array}$} & & \multicolumn{2}{|c|}{ Kafkas University } & \multicolumn{2}{|c|}{$\begin{array}{l}\text { Ömer Halisdemir } \\
\text { University }\end{array}$} & \multicolumn{2}{|c|}{ Total } \\
\hline & & $\mathrm{N}(245)$ & $\%$ & $\mathrm{~N}(246)$ & $\%$ & $\mathrm{~N}(491)$ & $\%$ \\
\hline \multirow{4}{*}{ Age } & $20-21$ & 30 & 12.2 & 37 & 15 & 67 & 13.6 \\
\hline & $22-23$ & 127 & 51.8 & 123 & 50 & 250 & 50.9 \\
\hline & $24-25$ & 44 & 18 & 50 & 20.3 & 94 & 19.1 \\
\hline & 26 and over & 44 & 18 & 36 & 14.6 & 80 & 16.3 \\
\hline \multirow{2}{*}{ Sex } & Female & 151 & 61.6 & 153 & 67.2 & 304 & 61.9 \\
\hline & Male & 94 & 38.4 & 93 & 37.8 & 187 & 38.1 \\
\hline \multirow{2}{*}{ Education level } & Graduate & 51 & 20.8 & 49 & 19.9 & 100 & 20.4 \\
\hline & Student & 194 & 79.2 & 197 & 80.1 & 391 & 79.6 \\
\hline \multirow{2}{*}{ Settlement } & Rural & 130 & 53.1 & 117 & 47.5 & 247 & 50.3 \\
\hline & Urban & 115 & 47 & 129 & 52.4 & 244 & 49.7 \\
\hline \multirow{3}{*}{ Faculty } & Arts and Science & 116 & 48.3 & 127 & 51.8 & 243 & 50.1 \\
\hline & FEAS & 35 & 14.6 & 61 & 24.9 & 96 & 19.8 \\
\hline & SPEA & 89 & 37.1 & 57 & 23.3 & 162 & 30.1 \\
\hline \multirow{6}{*}{$\begin{array}{l}\text { Mother's education } \\
\text { level }\end{array}$} & Illiterate & 68 & 27.8 & 31 & 12.6 & 99 & 20.2 \\
\hline & Literate & 25 & 10.2 & 12 & 4.9 & 37 & 7.5 \\
\hline & $\begin{array}{l}\text { Elementary } \\
\text { school }\end{array}$ & 92 & 37.6 & 130 & 52.8 & 222 & 45.2 \\
\hline & Middle school & 34 & 13.9 & 35 & 14.2 & 69 & 14.1 \\
\hline & High school & 17 & 6.9 & 33 & 13.4 & 50 & 10.2 \\
\hline & University & 9 & 3.7 & 5 & 2 & 14 & 2.9 \\
\hline \multirow{6}{*}{$\begin{array}{l}\text { Father's education } \\
\text { level }\end{array}$} & Illiterate & 9 & 3.7 & 5 & 2 & 14 & 2.9 \\
\hline & Literate & 26 & 10.7 & 9 & 3.7 & 35 & 7.1 \\
\hline & $\begin{array}{l}\text { Elementary } \\
\text { school }\end{array}$ & 88 & 36.1 & 102 & 41.5 & 190 & 38.8 \\
\hline & Middle school & 42 & 17.2 & 48 & 19.5 & 90 & 18.4 \\
\hline & High school & 54 & 22.1 & 59 & 24 & 113 & 23.1 \\
\hline & University & 25 & 10.2 & 23 & 9.3 & 48 & 9.8 \\
\hline \multirow{7}{*}{$\begin{array}{l}\text { Monthly family } \\
\text { income (TL) }\end{array}$} & $0-999$ & 17 & 6.9 & 15 & 6.1 & 32 & 6.5 \\
\hline & 1000-1999 & 56 & 22.9 & 87 & 35.4 & 143 & 29.1 \\
\hline & 2000-2999 & 55 & 22.4 & 66 & 26.8 & 121 & 24.6 \\
\hline & $3000-3999$ & 34 & 13.9 & 43 & 17.5 & 77 & 15.7 \\
\hline & $4000-4999$ & 14 & 5.7 & 17 & 6.9 & 31 & 6.3 \\
\hline & 5000 and above & 19 & 7.8 & 18 & 7.3 & 37 & 7.5 \\
\hline & Not marked & 50 & 20.4 & - & - & 50 & 10.2 \\
\hline
\end{tabular}


As seen in Table 1, 245 teacher candidates from Kafkas University and 246 teacher candidates from Ömer Halisdemir University participated in the study. The values of age, sex and education levels of the participants from both universities are close to each other. When the faculty variable is taken into account, it is seen that majority of the participants are either students or graduates of faculty of arts and sciences. It is also seen that the number of SPEA students or graduates of Kafkas University are higher than the number of SPEA students or graduates of Ömer Halisdemir University. When the mother and father education levels are taken into consideration, mother and father education levels of Kafkas University participants are found lower than mother and father education levels of Ömer Halisdemir University participants. When the income levels of the participants are examined, it can be said that income levels of participants from Kafkas University are lower compared to participants from Ömer Halisdemir University.

The study was conducted with a total of 491 participants. When the ages of the participants are examined, it is seen that the participants are mostly in the $22-23$ age group (50,9\%), female participants' ratio is higher than male participants, the number of undergraduate students is higher than the graduates and the ratio of participants living in rural areas to urban areas is nearly equal. $50.1 \%$ of the participants are the students or graduates of faculty of arts and sciences, $30.1 \%$ are of school of physical education and sports, and $19.8 \%$ are of faculty of economics and administrative sciences. While a significant portion of the participants' mothers are elementary school graduates $(45.2 \%)$ and illiterate $(20 \%)$, very few of them are university graduates $(2.9 \%)$. While a significant portion of the participants' fathers are elementary school graduates $(38.8 \%)$ and high school graduates $(23.1 \%)$, very few of them are illiterate $(2.9 \%)$. According to these results, education level of participants' fathers is higher than education level of participants' mothers. When participants' family incomes are examined, it is seen that most of them had family income of 1000-1999 TL (29.1\%) and very few of them had family income of 4000-4999 TL (6.3\%).

3.2 One-way ANOVA Results of Participants' Attitude Scale towards Teaching Profession Scores according to the Age Variable

Table 2 includes the participants' Attitude Scale towards Teaching Profession scores depending on their age levels

Table 2. One-way ANOVA results of participants' attitudes towards the teaching profession according to their ages.

\begin{tabular}{|c|c|c|c|c|c|c|c|}
\hline Dimension & $\begin{array}{l}\text { Source of } \\
\text { Variance }\end{array}$ & SS & $\mathrm{df}$ & MS & $\mathrm{F}$ & $\mathrm{p}$ & Significant Difference LSD \\
\hline \multirow{3}{*}{ Affection } & Between Group & 2474.94 & 3 & 824.98 & 4.05 & $.007 *$ & $1-4$ \\
\hline & Within Group & 98992.44 & 487 & 203.27 & & & $2-4$ \\
\hline & Total & 101467.38 & 490 & & & & $3-4$ \\
\hline \multirow{3}{*}{ Value } & Between Group & 84.45 & 3 & 28.15 & 1.38 & .247 & \\
\hline & Within Group & 9898.73 & 487 & 20.32 & & & \\
\hline & Total & 9983.18 & 490 & & & & \\
\hline \multirow{3}{*}{ Harmony } & Between Group & 66.46 & 3 & 22.15 & 1.21 & .303 & \\
\hline & Within Group & 8857.68 & 487 & 18.18 & & & \\
\hline & Total & 8924.15 & 490 & & & & \\
\hline \multirow{3}{*}{ Total } & Between Group & 3827.72 & 3 & 1275.90 & 3.23 & $.022 *$ & $1-4$ \\
\hline & Within Group & 191943.87 & 487 & 394.13 & & & $2-4$ \\
\hline & Total & 195771.60 & 490 & & & & $3-4$ \\
\hline
\end{tabular}

$* \mathrm{p}<.05$

As seen in table 2, participants' attitudes towards the teaching profession do not differ according to the age ranges in the value $[(\mathrm{F}(3 ; 490)=1.38 ; \mathrm{p}>.05]$ and harmony $[(\mathrm{F}(3 ; 490)=1.21 ; \mathrm{p}>.05]$ sub-dimensions. However, participants' attitudes towards the teaching profession significantly differ in the affection $[(\mathrm{F}(3 ; 490)=4.05 ; \mathrm{p}<.05]$ sub-dimension and within the total scale $[(\mathrm{F}(3 ; 490)=3.23 ; \mathrm{p}<.05]$ according to the age variable. Conducted to determine which groups' attitudes towards the teaching profession differ significantly according to the age variable, LSD test results show that 26 and over age group's ( $\bar{X}=92.13)$ mean scores from the scale are higher than the 20-21 age group's $(\bar{X}$ $=86.37)$ mean scores, $22-23$ age group's $(\bar{X}=85.81)$ mean scores and 24-25 age group's $(\bar{X}=87.21)$ mean scores in the affection sub-dimension. Within the total scale, it is seen that 26 and over age group's ( $\bar{X} 4=154.25)$ mean scores 
are higher compared to 20-21 age group ( $\bar{X}=147.07)$, 22-23 age group $(\bar{X}=146.44)$ and 24-25 age group $(\bar{X}=147.31)$. In this context, it can be stated that 26 and over age group has more positive attitude towards the teaching profession than the other age groups.

\subsection{T-test Results of Participants' Attitudes towards the Teaching Profession according to the Sex Variable}

Table 3 presents the independent t-test results of participants' attitudes towards the teaching profession according to the sex variable.

Table 3. Independent t-test results of participants' Attitude Scale towards Teaching Profession scores according to the sex variable

\begin{tabular}{lccccccc}
\hline Dimensions & Sex & $\mathrm{N}$ & $\overline{\mathrm{x}}$ & $\mathrm{sd}$ & $\mathrm{df}$ & $\mathrm{t}$ & $\mathrm{p}$ \\
\hline \multirow{2}{*}{ Affection } & Female & 304 & 87.74 & 14.72 & 489 & 1.081 & .280 \\
& Male & 187 & 86.29 & 13.81 & & & \\
\hline \multirow{2}{*}{ Value } & Female & 304 & 36.67 & 3.59 & 489 & 4.005 & $.001^{*}$ \\
& Male & 187 & 35.01 & 5.55 & & & \\
\hline \multirow{2}{*}{ Harmony } & Female & 304 & 24.91 & 4.07 & 489 & 1.147 & .252 \\
& Male & 187 & 24.45 & 4.56 & & & \\
\hline \multirow{2}{*}{ Total } & Female & 304 & 149.32 & 19.39 & 489 & 1.919 & .056 \\
& Male & 187 & 145.77 & 20.78 & & & \\
\hline
\end{tabular}

$* \mathrm{p}<.05$

As seen in Table 3, there is a significant difference between the teaching profession attitudes of female and male participants in the value sub-dimension $[(\mathrm{t}(489)=4.005 ; \mathrm{p}<.05]$. Female participants' mean scores $(\bar{X}=36.67)$ in the value sub-dimension of the scale are higher than the male participants' mean scores $(\bar{X}=35.01)$ in the same sub-dimension. Based on this result, female participants value the teaching profession more than the male participants. Although participants' attitudes towards the teaching profession did not show any significant difference according to sex in the affection, harmony sub-dimensions and within the total scale, it can be said that females' attitudes towards the teaching profession are more positive compared to the males.

3.4 T-test Results of Participants' Attitudes towards the Teaching Profession according to Participants' Education Level (Graduate/Student)

Table 4 includes the independent t-test results of participants' attitudes towards the teaching profession according to the education level variable.

Table 4. Independent t-test results of participants' Attitude Scale towards Teaching Profession scores according to the education level variable

\begin{tabular}{lllccccc}
\hline Dimensions & Education & $\mathrm{N}$ & $\overline{\mathrm{X}}$ & $\mathrm{sd}$ & $\mathrm{df}$ & $\mathrm{t}$ & $\mathrm{p}$ \\
\multirow{2}{*}{ Affection } & Graduate & 100 & 91.44 & 11.06 & 489 & 3.344 & $.001^{*}$ \\
& Student & 391 & 86.10 & 14.94 & & & \\
\hline \multirow{2}{*}{ Value } & Graduate & 100 & 36.96 & 3.32 & 489 & 2.292 & $.022^{*}$ \\
& Student & 391 & 35.80 & 4.74 & & & \\
\hline \multirow{2}{*}{ Harmony } & Graduate & 100 & 25.81 & 3.08 & 489 & 2.826 & $.005^{*}$ \\
& Student & 391 & 24.46 & 4.48 & & & \\
\hline \multirow{2}{*}{ Total } & Graduate & 100 & 154.21 & 15.01 & 489 & 3.538 & $.001^{*}$ \\
& Student & 391 & 146.37 & 20.79 & & & \\
\hline
\end{tabular}

$* \mathrm{p}<.05$

As seen in Table 4, there is a significant difference between the teaching profession attitudes of participants who graduated and teaching profession attitudes of participants who are still continuing their undergraduate degrees in the scale's affection [(t(489)=3.344; $<<.05]$, value $[(\mathrm{t}(489)=2.292 ; \mathrm{p}<.05]$ and harmony $[(\mathrm{t}(489)=2.826 ; \mathrm{p}<.05]$ sub-dimensions and within the total scale $[(\mathrm{t}(489)=3.568 ; \mathrm{p}<.05]$. Mean scores of participants who graduated from an 
undergraduate program and continuing this certificate program are higher than the mean scores of participants who are still attending an undergraduate program in the affection $(\bar{X}=91.44)$, value $(\bar{X}=36.96)$, harmony $(\bar{X}=25.81)$ sub-dimensions and within the total scale $(\bar{X}=154.21)$. This finding can be interpreted as participants who graduated from undergraduate programs having more positive attitudes than participants who are still attending undergraduate programs.

3.5 T-test Results of Participants' Attitudes towards the Teaching Profession according to the Universities Where Participants Take Their Pedagogical Formation Training

Table 5 presents the independent t-test results of participants' attitudes towards the teaching profession according to the university variable

Table 5. Independent t-test results of participants' Attitude Scale towards Teaching Profession scores according to the universities where participants take their pedagogical formation training

\begin{tabular}{|c|c|c|c|c|c|c|c|}
\hline Dimensions & University & $\mathrm{N}$ & $\bar{x}$ & $\mathrm{sd}$ & $\mathrm{df}$ & $\mathrm{t}$ & $\mathrm{p}$ \\
\hline \multirow[b]{2}{*}{ Affection } & Kafkas & 245 & 87.19 & 15.40 & 489 & .004 & .997 \\
\hline & $\begin{array}{l}\text { Ömer } \\
\text { Halisdemir }\end{array}$ & 246 & 87.18 & 13.33 & & & \\
\hline \multirow[b]{2}{*}{ Value } & Kafkas & 245 & 35.55 & 4.97 & 489 & 2.370 & $.018 *$ \\
\hline & $\begin{array}{l}\text { Ömer } \\
\text { Halisdemir }\end{array}$ & 246 & 36.52 & 3.95 & & & \\
\hline \multirow[b]{2}{*}{ Harmony } & Kafkas & 245 & 24.13 & 4.86 & 489 & 3.172 & $.002 *$ \\
\hline & $\begin{array}{l}\text { Ömer } \\
\text { Halisdemir }\end{array}$ & 246 & 25.34 & 3.48 & & & \\
\hline \multirow[b]{2}{*}{ Total } & Kafkas & 245 & 146.88 & 21.85 & 489 & 1.202 & .230 \\
\hline & $\begin{array}{l}\text { Ömer } \\
\text { Halisdemir }\end{array}$ & 246 & 149.05 & 17.92 & & & \\
\hline
\end{tabular}

As seen in Table 5, there is a significant difference between the teaching profession attitudes of participants from Kafkas University $[(\mathrm{t}(489)=2.370 ; \mathrm{p}<.05]$ and teaching profession attitudes of participants from Ömer Halisdemir University $[(\mathrm{t}(489)=3.172 ; \mathrm{p}<.05]$ in the scale's value, and harmony sub-dimensions. Mean scores of attitudes of participants from Ömer Halisdemir University $(\bar{X}=36.52)$ are higher than the mean scores of teaching profession attitudes of participants from Kafkas University $(\bar{X}=35.55)$ in the value sub-dimension of the scale. Mean scores of teaching profession attitudes of participants from Ömer Halisdemir University ( $\bar{X}=25.34)$ are higher in the harmony sub-dimension of the scale than the mean scores of teaching profession attitudes of participants from Kafkas University ( $\bar{X}=24.13)$ in the same sub-dimension. Based on this finding, it can be said that participants from Ömer Halisdemir University value teaching profession more than the participants from Kafkas University and that they believe they will be more compatible with the job. Although attitudes towards the teaching profession do not show any significant difference in the affection sub-dimension and within the total scale, it can be stated that students from Ömer Halisdemir University $(\bar{X}=149.05)$ have more positive attitudes towards the teaching profession than the students from Kafkas University ( $\bar{X}=146.88$ ).

3.6. T-test Results of Participants' Attitudes towards the Teaching Profession according to the Administrative Settlement Unit They Have Lived the Longest

Table 6 includes the independent t-test results of participants' attitudes towards the teaching profession according to the settlement lived in the longest variable 
Table 6. Independent t-test results of participants' Attitude Scale towards Teaching Profession scores according to the settlement lived in the longest variable

\begin{tabular}{|c|c|c|c|c|c|c|c|}
\hline Dimensions & $\begin{array}{l}\text { Settlement unit } \\
\text { lived in the } \\
\text { longest }\end{array}$ & $\mathrm{N}$ & $\bar{X}$ & sd & df & $\mathrm{t}$ & $\mathrm{p}$ \\
\hline \multirow{2}{*}{ Affection } & Rural & 247 & 86.08 & 14.15 & 489 & 1.721 & .086 \\
\hline & Urban & 244 & 88.31 & 14.57 & 489 & & \\
\hline \multirow{2}{*}{ Value } & Rural & 247 & 35.66 & 4.75 & 489 & 1.866 & .063 \\
\hline & Urban & 244 & 36.42 & 4.22 & 489 & & \\
\hline \multirow{2}{*}{ Harmony } & Rural & 247 & 24.44 & 4.24 & 489 & 1.549 & .122 \\
\hline & Urban & 244 & 25.04 & 4.27 & 489 & & \\
\hline \multirow{2}{*}{ Total } & Rural & 247 & 146.19 & 19.51 & 489 & 1.999 & $.047 *$ \\
\hline & Urban & 244 & 149.77 & 20.34 & 489 & & \\
\hline
\end{tabular}

$* \mathrm{p}<.05$

As seen in Table 6, there is not a significant difference between the teaching profession attitudes of participants in the affection, value and harmony sub-dimensions according to the administrative settlement unit the participants lived in the longest. However, it is seen that there is a significant difference in participants' attitudes towards the teaching profession within the total scale according to the administrative settlement unit the participants lived in the longest $[(\mathrm{t}(489)=1.999 ; \mathrm{p}<.05]$. Based on Table 6 , mean scores of teaching profession attitudes of participants who lived in urban areas the longest $(\bar{X}=149.77)$ are higher than the mean scores of teaching profession attitudes of participants who lived in the rural areas the longest $(\bar{X}=146.19)$ within the total scale. According to this finding, it can be said that the teaching profession attitudes of participants who lived in the urban areas the longest are more positive than the teaching profession attitudes of participants who lived in rural areas the longest.

In the study, it is determined that pedagogical formation program participants' attitudes do not differ according to participants' faculties, mother and father's education level and monthly family income.

\section{Discussion}

Aiming to make permanent changes in individuals' behaviors, teaching profession can only improve as long as there are teachers with positive attitudes towards the profession in addition to improvements in quality, technical knowledge and skills. Individuals will love the job, value it and who will be compatible with it becoming teachers will not only help the improvement of the quality of the teaching profession but also help the improvement of the quality of education in general. Thus, positive attitudes towards the teaching profession are important as the technical knowledge and skills teachers must have to do the teaching profession. In this study, teaching profession attitudes of teacher candidates' enrolled in two different pedagogical formation certificate programs, one of the teacher training processes in Turkey, were examined. In this way, the factors related to the attitudes towards the teaching profession were determined. In this framework, the study tried to answer the question of whether teacher candidates' attitudes towards the teaching profession differed or not according to the age, education level, sex, mother-father education level, monthly family income, settlement they lived the longest and university where the pedagogical formation training took place variables. The following results were reached as a result of the study:

The teaching profession attitudes of participants who are older are more positive compared to other participants. This study result is similar to the study results of Ertem and Kete (2015) and Özkan (2012). Both of these studies put forth that older participants' attitudes towards the teaching profession are higher than the other participants. Teaching profession attitudes of participants who graduated from an undergraduate program are higher than the teaching profession attitudes of participants who are still continuing their undergraduate degrees. Considering the fact that participants who graduated from an undergraduate program are older than the participants who are still continuing their undergraduate programs, this result can be related to the participants' ages. On the other hand, another reason why teaching profession attitudes of participants who graduated from an undergraduate program are more positive is that they might have shed their student roles and started to look to teaching from a certain distance. In this context, participants who are still continuing their undergraduate programs are carrying their student roles with them, and this might have negatively affected their attitudes towards teaching. This can be associated with the unequal hierarchical relationship between the student and teacher roles. 
When examining whether participants' attitudes towards teaching differ according to sex, it is seen that attitudes towards the teaching profession are higher only in the value sub-dimension in favor of female participants. On the other hand, it is concluded that there is no significant difference in all of the scale's sub-dimensions according to the sex variable. While this study result supports the results of studies (Açıllş \& Kolomuç, 2012; Bulut, 2009; Özder, Konetralı \& Zeki, 2010) indicating that the sex variable does not change the attitudes towards the teaching profession, it also contradicts the study results (Aksoy 2010; Terzi \& Tezci, 2007; Çapa \& Çil, 2000; Dönmez \& Uslu, 2013; Camadan \& Duysak, 2010; Akpınar, Yıldız \& Ergin, 2006) pointing out that female participants exhibit more positive attitudes towards teaching compared to male participants. Based on the fact that teaching is compatible with the womanhood roles in the distribution of dominant gender roles and that teaching seen as a women's job, they emphasize that women approach teaching more positively than men. On the other hand, the existence of studies revealing different results point out that gender roles might affect attitudes towards teaching profession rather than biological roles. Therefore, conducting studies on the same subject but differentiating between biological sex roles and gender roles might be meaningful. The fact that these studies are qualitative studies can also help with making sense of the related difference.

As a result of the study, it was determined that mother and father's education levels did not create significant differences in terms of participants' attitudes towards teaching. Indeed, studies (İlğan, Sevinç \& Arı, 2013; Kartal \& Afacan, 2012; Orhan \& Ok, 2014) examining similar subjects have reached a similar result. On the other hand, in Tekerek and Polat's (2011) study revealed that mother's education level was effective on attitudes but father's education level did not create any significant difference. In the current study, it was determined that monthly family income in addition to family education level did not lead to a significant difference in terms of attitudes. This result supports the results of Yeşil (2011), Gökçe and Sezer (2012) and Güneyli and Aslan (2009). Based on these results, it can be said that participants' family characteristics do not create a significant difference on attitudes towards the teaching profession.

When examining whether participants' attitudes towards teaching differ according to where participants lived the longest or not, it is seen that participants who lived in urban areas the longest had more positive attitudes towards the teaching profession compared to participants who lived in rural areas the longest. This result is in contradiction with the study results of Eraslan and Çakıcı (2011) and Karatekin, Merey and Keçe (2015). Hence, it possible this sis related to the sociocultural, economic and geographical characteristics of urban and rural areas rather than participants just living in urban and rural areas. In order to find detailed answers to this, it would be meaningful to conduct studies that will discuss settlement area's different socioeconomic and cultural characteristics as variables rather than discussing the areas as variables.

One of the most important results of the current study is that participants' attitudes differ according to the universities here the participants take the pedagogical formation certificate program. Attitudes of participants who were enrolled in two different universities significantly differed in value and harmony sub-dimensions and within the total scale. This study result is similar to the study results of Tekerek and Polat (2011) and Parvez and Shakir (2013). In this context, it is possible to say that the institution where the pedagogical formation certificate program is offered, the content of the teacher training programs and the processes experienced in the programs might affect the attitudes towards teaching profession. For this reason, conducting new studies that will examine the relationship between attitudes and institutions is necessary. This study result is important because processes related to teaching training affect the attitudes towards teaching. Even though the teacher candidates come to the teacher training programs with certain attitudes, processes they experience during the teacher training might affect their attitudes differently. Therefore, understanding teacher candidates' attitudes during the teacher training processes and deducing what needs to be done in order to change these attitudes are vital.

\section{Acknowledgement}

We thank all the teacher candidates who voluntarily participated in the study.

\section{References}

Akpınar, E., Yıldız, E., \& Ergin, Ö. (2006). Fen bilgisi öğretmen adaylarının öğretmenlik mesleğine yönelik tutumları. Dokuz Eylül Üniversitesi Buca Eğitim Fakültesi Dergisi, 19, 56-62. https://doi.org/10.2307/3004873

Anderson, W.A. (1928). The occupational attitudes and choices of a group of college men. Part II. Social Forces, 6(3), 467-473.

Açılış, S. \& Kolomuç, A. (2012). Study of the would-be class teachers' attitude towards the profession. Journal of Research in Education and Teaching, 1(2), 266-271. 
Aksoy, M. E. (2010). Öğretmen adaylarının öğretmenlik mesleğine ilişkin tutumları (Gaziosmanpaşa Üniversitesi örneği). Sosyal Bilimler Araştırmaları Dergisi, 2, 197-212.

Bulut, İ. (2009). Evaluation of teacher candidates' attitudes concerning teaching profession (Dicle and Frrat University sample). Dicle Üniversitesi Ziya Gökalp Eğitim Fakültesi Dergisi, 14, 13-24.

Camadan, F. \& Duysak, A. (2010). Farklı programlardaki öğretmen adaylarının öğretmenlik mesleğine yönelik tutumlarının çeşitli değişkenler açısından karşılaştııılması: Rize Üniversitesi örneği. International Conference on New Trends in Education and Their Implications. 11-13 November, 2010 Antalya-Turkey.

Cohen, D. K. (1988). Teaching practice: Plus ça change. The National Center Research on Teacher Education. Issue Paper, 88-3.

Çapa, Y. \& Çil, N. (2000). Öğretmen adaylarının öğretmenlik mesleğine yönelik tutumlarının farklı değişkenler açısından incelenmesi. Hacettepe Üniversitesi Ĕ̈itim Fakültesi Dergisi, 18, 69-73.

Çetin, Ş. (2006). Öğretmenlik mesleği tutum ölçeğinin geliştirilmesi (geçerlik ve güvenirlik çalışması). Gazi Üniversitesi Endüstriyel Sanatlar Eğitim Fakültesi Dergisi, 18, 28-37.

Dikmenli, Y. \& Çiftçi, T. (2016). Geography teachers' attitudes and beliefs regarding classroom management. International Journal of Higher Education, 5(2), 283-291. https://doi.org/10.5430/ijhe.v5n2p283

Donaldson, G. (2013). The twenty-first century professional. In V.V. Vidovic \& Z. Velkovski (Eds.). Teaching profession in 21 st century (pp. 13-24), Centre for Education Policy.

Dönmez, C. \& Uslu, S. (2013). Sosyal bilgiler öğretmen adaylarının öğretmenlik mesleğine yönelik tutumları. Türk Eğitim Bilimleri Dergisi, 11(1), 42-63.

Eraslan, L. \& Çakıc1, D. (2011). Pedagogical formation program students 'attitudes towards teaching profession. Kastamonu Ĕ̈itim Dergisi, 19(2), 427-438.

Ertem, S. \& Kete, R. (2015). Formasyon öğretmen adaylarının mesleki tutum ve beklentilerinin farklı değişkenlere göre karşılaştırılması. VII. Ulusal Lisansüstü Eğitim Sempozyumu Bildiriler Kitabı.72-81.

Flores, M. A. (2001). Person and context in becoming a new teacher. Journal of Education for Teaching, 27(2), 135-148. https://doi.org/10.1080/02607470120067882

Gökçe, F. \& Sezer, G.O. (2012). The attitudes of student teachers towards teaching profession: Uludag University sample. Uludă̆ Üniversitesi Eğitim Fakültesi Dergisi, 25(1), 1-23.

Güneyli, A. \& Aslan, C. (2009). Evaluation of Turkish prospective teachers' attitudes towards teaching profession (Near East University case). Procedia Social and Behavioral Sciences, 1, 313-319. https://doi.org/10.1016/j.sbspro.2009.01.059

Hollingsworth, S. (1989). Prior beliefs and cognitive change in learning to teach. American Educational Research Journal, 26(2), 160-189. https://doi.org/10.3102/00028312026002160

İlğan, A., Sevinç, Ö. S., \& Arı, E. (2013).The perceptions of teachers' towards professional attitude contemporary teachers qualifications. Ondokuz Mayls Üniversitesi Ĕgitim Fakültesi Dergisi, 32(2), 175-195. https://doi.org/10.7822/egt255

Kagan, D. M. (1992). Professional growth among preservice and beginning teachers. Review of Educational Research. 62(2), 129-169. https://doi.org/10.3102/00346543062002129

Karagözoğlu, G. (1987). Yükseköğretime geçişte öğretmenlik mesleğine yönelme. Hacettepe Üniversitesi Eğitim Fakültesi Dergisi, (2), 34-46.

Karasar, N. (2012). Bilimsel araştırma yöntemi. (23th. ed.). Ankara: Nobel Yayıncılık.

Karatekin, K. \& Merey, Z. \& ve Keçe, M. (2015). Analysis of the attitudes of the social studies pre-service teachers towards teaching profession. YYÜ Eğitim Fakültesi Dergisi (YYU Journal of Education Faculty), 12(1), 70-96.

Kartal, T. \& Afacan, Ö. (2012). Examining attitudes of prospective teachers who took pedagogical formation education towards teaching profession. Mehmet Akif Ersoy Üniversitesi Eğitim Fakültesi Dergisi, 24, 76-96.

Katz, D. (1960). The functional approach to study of attitudes. Public Opinion Quarterly, 24(2), 163-204. https://doi.org/10.1086/266945

Khalid, M. \& Amir, S. (2014). Teaching as future profession - exploring business students' attitudes toward teaching profession. Proceedings of SOCIOINT14- International Conference on Social Sciences and Humanities, 
726-731. 8-10 September 2014- Istanbul, Turkey.

Lasky, S. (2005). A sociocultural approach to understanding teacher identity, agency and professional vulnerability in a context of secondary school reform. Teaching and Teacher Education, 21, 899-916. https://doi.org/10.1016/j.tate.2005.06.003

OECD. (2005). Teachers matter: Attracting, developing and retaining effective teachers. Oecd Publishing. Retrived from http://www.oecd.org/edu/school/34990905.pdf

Oktay, A. (1991). Öğretmenlik mesleği ve öğretmenin nitelikleri. M. Ü. Atatürk Eğitim Fakültesi Ĕgitim Bilimleri Dergisi, 3, 187-193.

Orhan, E.E. \& Ok, A. (2014). Who prefer teacher education programs? Candidates' entry characteristics and attitude towards teaching. Hacettepe Üniversitesi Eğitim Fakültesi Dergisi (H. U. Journal of Education), 29(4), 75-92.

Özder, H., Konetralı, G., \& Zeki, C. P. (2010). Examining the attitudes towards the teaching profession and academic achievements of prospective teachers. Educational Administration: Theory and Practice, 16(2), 253- 275.

Özkan, H.H. (2012). Investigation of pre-service teachers' attitudes towards teaching profession in a teaching formation certification program (SDÜ sample). Ahi Evran Üniversitesi Kırşehir Eğitim Fakültesi Dergisi (KEFAD), 13(2), 29-48.

Parvez, M. \& Shakir, M. (2013). Attitudes of prospective teachers towards teaching profession. Journal of Education and Practice, 4(10), 172-178.

Pajares, M. F. (1992). Teachers' beliefs and educational research: Cleaning up a messy construct. Review of Educational Research, 62(3), 307-332. https://doi.org/10.3102/00346543062003307

Polat, S. (2013). Investigating the attitudes of students from pedagogical formation certificate programs and faculties of education on the profession of teaching. E-International Journal of Educational Research, 4(2), 48-60.

Prislin, R. \& Crano, W. (2010). Attitudes and attitude change. (Editors: Radmila Prislin; William D. Crano). Taylor\&Francis e Library.

Rokeach, M. (1967). Attitude change and behavioral change. Public Opinion Quarterly, 30(4), 529-550. https://doi.org/10.1086/267454

TDK. (2017). $\quad$ Tutum. $\quad$ Retrieved from http://www.tdk.gov.tr/index.php?option=com_bts\&arama=kelime\&guid=TDK.GTS.58cbae45e4d881.94359355

Tekerek M. \& Polat, S. (2011). Preservice teacher's attitudes towards teaching profession. 5th International Computer \& Instructional Technologies Symposium, 22-24 September 2011, Firat University, Elazığ- Turkey.

Tekışık, H. H. (1987). Türkiye'de öğretmenlik mesleği ve sorunları. Hacettepe Üniversitesi Eğitim Fakültesi Dergisi, 2, 24-33.

Terzi, A.R. \& Tezci, E. (2007). The attitudes of the students towards teaching profession at Necatibey Education Faculty. Educational Administration: Theory and Practice, 52, 593-614.

Valcke M. \& Sang G. \& Rots, I. \& Hermans, R (2010). Taking prospective teachers' beliefs into account in teacher education. In: Penelope Peterson, Eva Baker, Barry McGaw, (Editors), International Encyclopedia of Education, 7, 622-628. Oxford: Elsevier.

Yeşil, H. (2011). Turkish language teaching students' attitudes towards teaching profession. International Online Journal of Educational Sciences, 3(1), 200-219.

Watt, H. M.G. \& Richardson, P. W. (2008). Motivations, perceptions, and aspirations concerning teaching as a career for different types of beginning teachers. Learning and Instruction 18, 408-428. https://doi.org/10.1016/j.learninstruc.2008.06.002 


\section{Appendix}

The scale used as the data collection tool

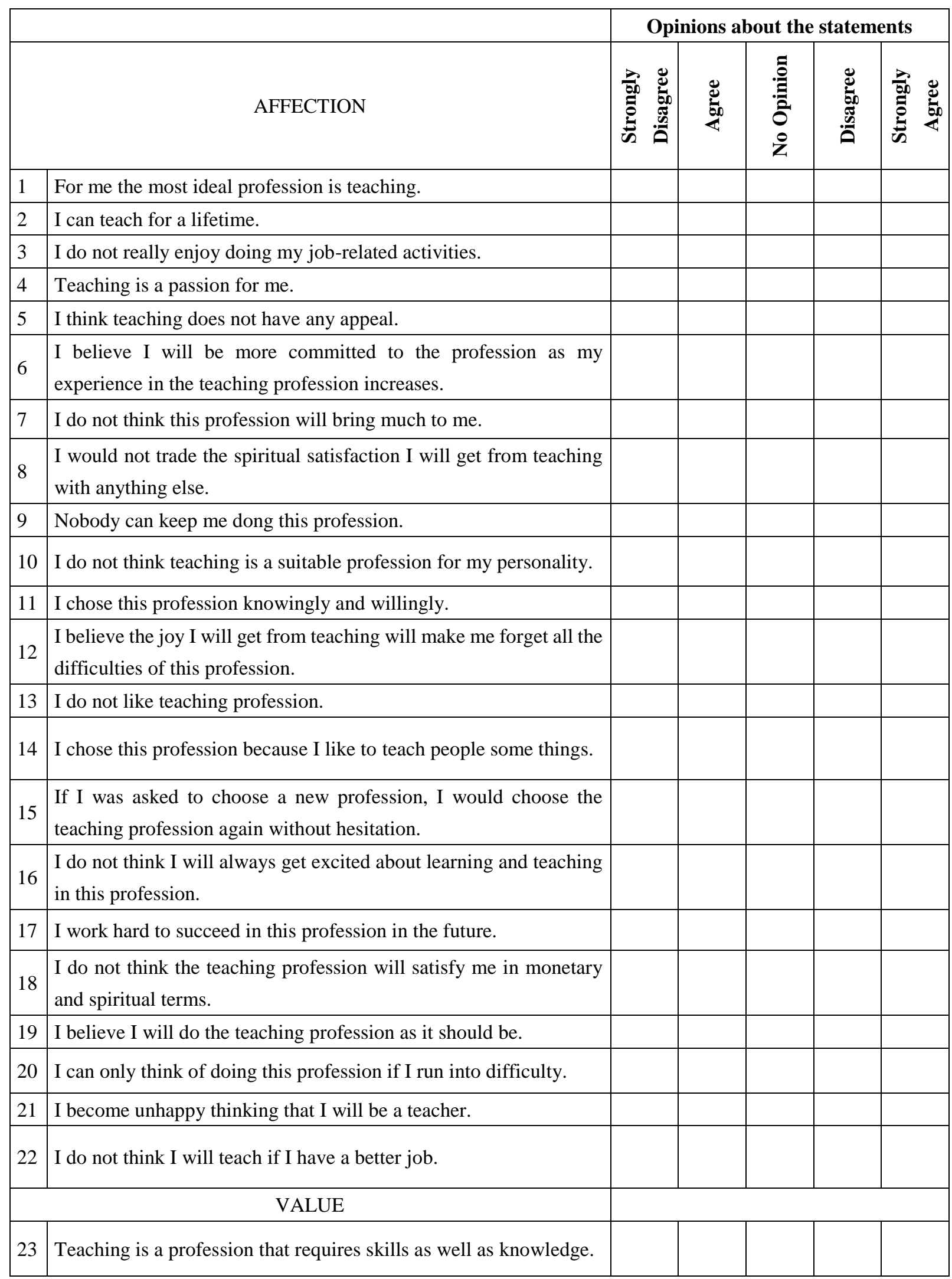




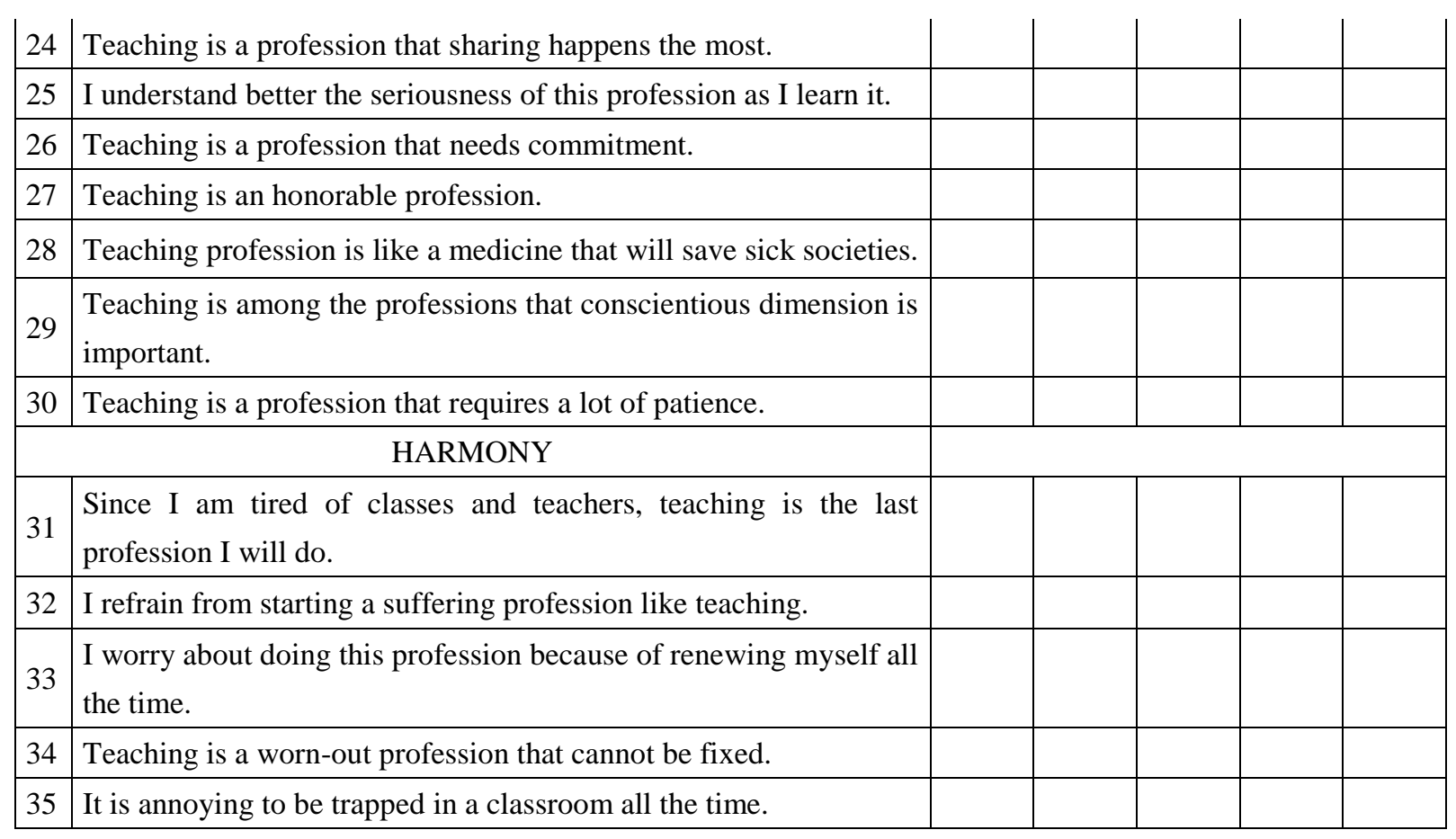

